\title{
KIELENVAIHTO MONIKIELISISSÄ KOKOUKSISSA - OSALLISTUJIEN KIELITAITO JA VUOROVAIKUTUKSEN SUJUVA ETENEMINEN ${ }^{1}$
}

\author{
Lari Kotilainen, suomen kieli, Helsingin yliopisto \\ Inkeri Lehtimaja, suomen kieli, Helsingin yliopisto
}

Yhä useammilla suomalaisilla työpaikoilla puhutaan kotimaisten kielten lisäksi myös muita kieliä, esimerkiksi englantia tai maahanmuuttajakieliä. Uusi kielitilanne johtaa vuorovaikutuksen haasteisiin, sillä kaikki työntekijät eivät välttämättä osaa hyvin kaikkia työkieliä. Tässä artikkelissa esittelemme tapoja, joilla työntekijät hyödyntävät työympäristön monikielisyyttä varmistaakseen mahdollisimman tehokkaasti etenevän vuorovaikutuksen. Tarkemman kiinnostuksen kohteena ovat kohdat, joissa vaihdetaan puhuttavaa kieltä. Aineistonamme on videoituja työkokouksia suomalaisesta kulttuurialan järjestöstä. Kokousten yleisimmät kielet ovat suomi ja venäjä. Metodinamme on etnometodologinen keskusteluntutkimus, eli tarkastelemme kielenvaihtoja vuorovaikutuksen mikrotason käytänteinä. Lähestymme monikielisen työvuorovaikutuksen käytänteitä sellaisten kielenvaihtojen kautta, jotka liittyvät vuorovaikutuksen etenemisen ongelmakohtiin. Tarkastelemme ensinnäkin sitä, missä tilanteissa ja miten osallistujat vaihtavat itselleen vahvempaan kieleen, ja toisaalta sitä, mitkä tekijät saavat heidät vaihtamaan vastaanottajalle vahvempaan kieleen. Tarkastelemamme kielenvaihdot liittyvät ongelmiin joko puheen tuottamisessa, ymmärtämisessä tai aktiivisessa vastaanottajuuden osoittamisessa. Vaihtamalla kieltä joustavasti tilanteen vaatimusten mukaan - ja toisinaan vastoin eksplisiittisiä sopimuksia käytettävästä kielestä - osallistujat varmistavat, että kokousvuorovaikutus etenee ja kaikilla kokouksen osanottajilla on mahdollisuus osallistua vuorovaikutukseen mahdollisimman täysipainoisesti.

Avainsanat: kielenvaihto, kielitaito, kokousvuorovaikutus, monikielisyys, työelämän kieli, vuorovaikutuksen eteneminen

\footnotetext{
${ }^{1}$ Artikkelissa kuvattu tutkimus on tehty Koneen Säätiön rahoittamassa Suomen kielen tilanteinen oppiminen -hankkeessa. Kirjoittajat ovat tasavertaisesti vastuussa lopputuloksesta. Kiitämme lämpimästi Katariina Harjunpäätä, Salla Kurhilaa ja kahta anonyymia refereetä tämän artikkelin aiempaan versioon saamistamme kommenteista.
}

Kirjoittajien yhteystiedot:

Lari Kotilainen

lari.kotilainen@helsinki.fi

Inkeri Lehtimaja

inkeri.lehtimaja@helsinki.fi

\section{JOHDANTO}

Useilla työpaikoilla monikielisyys on arkipäivää (ks. esim. EK, 2014). Työpaikan virallinen kieli saattaa olla esimerkiksi englanti, mutta monissa tilanteissa käytetään kuitenkin ympäröivän yhteiskunnan valtakieltä. Yhtä lailla 
tyypillistä on, että suomalaisella työpaikalla puhutaan periaatteessa vain suomea, mutta siitä tehdään kuitenkin tarpeen mukaan poikkeamia englantiin tai johonkin muuhun kieleen. Työyhteisöjen monikieliset käytänteet ovat kuitenkin harvoin yksiselitteisiä (esim. Lønsmann, 2014; Lüdi, Höchle \& Yanaprasart, 2016; Negretti \& Garcia-Yeste, 2015). Käytettävän kielen valintaan vaikuttavat paitsi yleisen tason periaatteet myös ruohonjuuritason tilanteet, niiden osallistujat ja osallistujien kielelliset resurssit. Tällaisessa dynaamisessa kieliympäristössä (dynamic language scenario, Hazel \& Mortensen, 2013, s. 4) työntekijöiden on koko ajan suhteutettava puhettaan omiin ja toisten kielellisiin resursseihin eli kykyyn toimia eri kielillä. Vuorovaikutuksen tasolla tämä näkyy esimerkiksi kielenvaihtojen tilanteisuutena: kieli voi periaatteessa vaihtua milloin vain vuorovaikutustilanteen jonkin osatekijän vaikutuksesta.

Kielten tilanteista vaihtelua on tutkittu usein ympäristöissä, joissa puhujat hallitsevat kahta tai useampaa kieltä (erittäin) hyvin (esim. Auer, 1998; Gafaranga, 2016). Työelämässä tilanne ei kuitenkaan ole aina näin ruusuinen: työntekijöiden kielitaito eri kielissä voi vaihdella auttavasta erinomaiseen. Koska monia aloja vaivaa työvoimapula, ei työpaikan kielitaitovaatimuksia ole myöskään välttämättä tarkoituksenmukaista pitää erityisen korkeina (ks. työelämän kielitaitovaatimuksista tarkemmin esim. Tarnanen \& Pöyhönen, 2011; Tervola, 2018). Työntekijä, joka ei osaa kovin hyvin kaikkia yrityksen työkieliä, voi muiden kielten ja työtovereitten tuella ja yhteisten pelisääntöjen avulla sekä osallistua mahdollisimman täysipainoisesti työyhteisön toimintaan että kehittää itseään kielenkäyttäjänä. Tällaisen tavoitteen saavuttamiseksi tarvitaan kuitenkin tietoa monikielisen vuorovaikutuksen käytänteistä. Tarkempi tieto esimerkiksi siitä, millaiset mekanismit vaikuttavat työelämän tilanteissa kielten vaihtelun taustalla, voisi aut- taa työnantajia ja työntekijöitä toteuttamaan aktiivista ja tietoista kielipolitiikkaa niin, että kielten vaihtelu työpaikalla edistäisi työtehtävien hoitamista, tukisi työntekijöiden kielenoppimista ja vahvistaisi sosiaalisia suhteita.

Tämä artikkeli tuottaa mainitunlaista tutkimustietoa työelämävuorovaikutuksen kielenvaihdoista. Tutkimuksemme tavoitteena on selvittää, miten kokousten osallistujat käyttävät kielenvaihtoja tilanteissa, joissa vuorovaikutuksen etenemiseen tulee ongelma. Aineistomme koostuu kulttuurialan järjestön videoiduista kokouksista. Niiden leimallinen piirre on se, että yhden kokouksen aikana käytetään yleensä useita kieliä; pääkielet ovat suomi ja venäjä. Keskitymme tässä artikkelissa tilanteisiin, joissa kieltä vaihdetaan jonkinlaisen vuorovaikutuksen ongelman seurauksena. Metodimme on keskustelunanalyysi (Stevanovic \& Lindholm, 2016), jonka avulla pääsee kiinni kielenvaihdon periaatteisiin hetki hetkeltä etenevässä vuorovaikutuksessa.

Aloitamme artikkelin esittelemällä aiempaa aihealueen kirjallisuutta. Kirjallisuuskatsauksen jälkeen esittelemme tarkemmin aineiston ja tutkimuksen metodin. Itse analyysiosa jakautuu kahteen lukuun sen mukaan, millaisesta positiosta kielenvaihtaja vaihtonsa tekee. Ensin esittelemme tapauksia, joissa kielenvaihtoa motivoi vaihtajan oman kielitaidon rajallisuus. Toisessa analyysijaksossa kielenvaihtaja orientoituu toisten kielitaitoon. Loppuluvussa pohdimme vielä tutkimuksen implikaatioita monikielisten työpaikkojen vuorovaikutuskäytänteiden kannalta.

\section{TYÖPAIKAN KIELIVALINNAT JA MONIKIELISYYS}

Monikielisten työpaikkojen vuorovaikutuksen haasteet ovat olleet viime aikoina tutkimuskirjallisuudessa esillä monien Euroopan maiden konteksteissa: esimerkiksi Suomessa Tanner ja Lassus (2018), Breckle ja Schlabach 
(2017) ja Lahti (2015), Ruotsissa Negretti ja Garcia-Yeste (2015), Tanskassa Lønsmann ja Mortensen (2018) ja Lønsmann (2014) sekä Sveitsissä Lüdi, Höchle ja Yanaprasart (2016). Aihetta on käsitelty vastikään myös esimerkiksi Journal of Pragmaticsin (ks. Hazelin ja Svennevigin, 2018, johdanto) ja Multilinguan (ks. Angourin, 2014, johdanto) erityisnumeroissa. Puhe ja kieli -lehdessä taas julkaistiin jo vuonna 2011 teemanumero suomesta toisena kielenä työelämässä (ks. Sunin, 2011, esipuhe). Monipuolista tutkimusta eri konteksteista tarvitaan jo siksi, että eri maissa kielten keskinäiset suhteet ovat erilaisia. Esimerkiksi pohjoismaisissa tutkimuksissa toistuu usein asetelmana lingua franca -englannin ja yhteiskunnan pääkielen suhde (esim. Suomessa Louhiala-Salminen \& Kankaanranta, 2012; Virkkula 2008). Oma aineistomme tarjoaa toisenlaisen näkökulman suomalaisten työpaikkojen monikielisyyteen, sillä kielinä ovat suomi ja venäjä.

Työpaikkojen monikielisyyttä on lähestytty niin yleisemmän tason periaatteista kuin käytännön tilanteista käsin. Lähtökohtanamme tässä artikkelissa on jälkimmäinen eli tilanteinen vuorovaikutus, sillä kuten esimerkiksi Lesk, Lavric ja Stegu (2017, s. 282-283) toteavat, yritysmaailman sisäisessä viestinnässä yrityksen ylemmän kielipoliittisen tason linjaukset heijastuvat vain osin työntekijöiden käytännön valintoihin. Lesk, Lavric ja Stegu (mp.) esittävät, että viralliseksi kieleksi nimettyä kieltä käytetään usein esimerkiksi sähköposteissa ja muissa kirjallisissa materiaaleissa, mutta erityisesti epävirallisemmassa suullisessa viestinnässä kielivalintaa ohjaavat 1) praktisuus eli parhaiten yhteisesti osatun kielen valinta, 2) halu harjoitella jotakin kieltä, 3) halu tehdä vaikutus kielitaidolla tai pelko huonon vaikutuksen tekemisestä ja 4) kohteliaisuus eli sen kielen valinta, jonka uskotaan olevan toiselle mieluisin. Nämä periaatteet toteutuvat ja näkyvät monin tavoin juuri hetkittäin etene- vässä vuorovaikutuksessa, johon keskitymme artikkelissamme.

Tutkimalla monikielisyyttä tilanteisen vuorovaikutuksen näkökulmasta jatkamme sitä Auerista $(1984,1998)$ alkanutta traditiota, joka korostaa kielenvaihtojen merkitystä nimenomaan vuorovaikutuksen rakentumisen tasolla eikä esimerkiksi vain lauseen sisäisenä ilmiönä tai vain laajempana sosiaalisen identiteetin ilmaisun keinona (ks. jaosta Auer, 1998, s. 3-13; Gafaranga, 2005, s. 291-292). Auer ja häntä edeltänyt diskurssin tason kielenvaihtojen pioneeri Gumperz (esim. 1982) käyttävät kielten vaihtelusta useimmiten termiä koodinvaihto (samoin myös suomen kieltä koskevissa tutkimuksissa mm. Kalliokoski, 1995; Lappalainen 2009; Frick, 2013; Mononen, 2013, s. 182-209). Tästä perinteestä poiketen käytämme tässä artikkelissa nimitystä kielenvaihto, sillä haluamme korostaa aineiston kielenvaihtojen asemaa nimenomaan kielitaitoon liittyvänä kommunikaatiostrategiana. Koodinvaihto-termillä on lisäksi ainakin toisen kielen tutkimuksissa usein korostettu eri kielten käyttöä merkkinä puhujan kyvystä käyttää hyödyksi esimerkiksi eri kielten tyylillistä potentiaalia (ks. Kalliokoski, 1995).

Tässä artikkelissa keskeinen pyrkimyksemme on tarkastella kielenvaihtoja osana hetki hetkeltä etenevää vuorovaikutusta, osallistujien tekemiä valintoja ja reaktioita näihin valintoihin (ks. myös Nevile \& Wagner, 2011, s. 214). Tavallinen vuorovaikutuksen periaate on, että vuoro - erityisesti responsiivinen vuoro - esitetään samalla kielellä kuin edeltävä vuoro (esim. Auer, 1984, s. 50-52). Tämä pätenee myös institutionaalisiin keskusteluihin: esimerkiksi monikielistä ja monenkeskistä yliopistollista arviointikeskustelua analysoineet Nevile ja Wagner (2011) nostavat esiin saman periaatteen. Miksi kieli sitten ylipäänsä vaihtuu institutionaalisessa vuorovaikutuksessa? Nevile ja Wagner tarjoavat kysymykseen yhden vastauksen esittämällä 
toisenkin periaatteen, jonka mukaan monikielisessä vuorovaikutustilanteessa jokaisella osallistujalla voi olla myös oma kielensä (mas. 218), jota kutsumme seuraavassa osallistujan omaksi oletuskieleksi (ks. myös termi preferred language, Auer, 1984). Nevilen ja Wagnerin ajatus liittyy nimenomaan kielitaitoon: yleensä puhujat käyttävät edellisten vuorojen kieltä, paitsi silloin kun oma - tai erityisesti monenkeskisessä keskustelussa uuden vastaanottajan - kielitaito ei riitä. On tärkeää huomata, että oletuskieli ei ole välttämättä sama kuin äidinkieli, sillä oletuskieli määrittyy suhteessa vuorovaikutuksen muihin osallistujiin ja heidän hallitsemiinsa kieliin. Esimerkiksi ulkomaille työmatkalle lähtevän suomenkielisen oletuskieli on useissa tilanteissa englanti. Tässä mielessä oma oletuskieli on siis tilanteinen.

Kokeilemme seuraavassa edellä esitettyjen kielenvalintaa säätelevien periaatteiden - vuoro tuotetaan edellisen vuoron kielellä ja vuoron kielenvalintaan vaikuttaa oma tai vastaanottajan oletuskieli - soveltuvuutta suomalaisen työpaikka-aineiston kielenvaihtelun analysointiin. Ennen analyysiosaa esittelemme tutkimuksemme aineiston ja kerromme tarkemmin artikkelissa sovelletusta metodista.

\section{TYÖPAIKKAKOKOUSAINEISTO JA KESKUSTELUNANALYYSI}

Olemme videoineet syksyn 2017 ja kevään 2018 aikana suomalaisesta kulttuurialan järjestöstä noin 25 tuntia työkokouksia, joissa käytetään pääosin suomea ja venäjää. Osa kokouksista pidetään järjestön oman väen kesken ja osa yhteistyökumppanien kanssa. Kokouksiin osallistuu yhteensä 22 henkilöä, joilta kaikilta saatiin etukäteen lupa tutkimusaineiston keruuseen ja käyttöön. Useimmat osallistujat osaavat sekä suomea että venäjää, mutta hyvin eri tasoilla. Englantia käytetään ylipäänsä vähän, mutta siihen orientoidutaan kaikkien osaamana kielenä (vrt. Lønsmann, 2014).

Aineiston kokoukset ovat luonteeltaan vapaamuotoisia: niissä ei ole muodollista esityslistaa eikä niillä ole yksiselitteistä puheenjohtajaa (ks. puheenjohtajan roolista esim. Svennevig, 2012, s. 5-6). Tilanteet poikkeavat silti monin tavoin arkivuorovaikutuksesta. Kokouksilla on esimerkiksi aina jokin järjestön käynnissä oleviin hankkeisiin liittyvä tavoite, kuten hankkeen suunnittelu, apurahahakemuksen työstäminen tai viestinnän periaatteista ja yksityiskohdista sopiminen. Lisäksi osallistujat toimivat kokouksissa omissa työrooleissaan (esim. esimiehinä tai alaisina, järjestön tai yhteistyötahojen edustajina).

Tutkimusmetodina käytämme etnometodologista keskustelunanalyysiä (Stevanovic \& Lindholm, 2016), joka perustuu tallennettujen, autenttisten vuorovaikutustilanteiden systemaattiseen tarkasteluun. Metodin avulla pystytään analysoimaan vuorovaikutuksen osallistujien näkyvää toimintaa ja sen lainalaisuuksia: jokaisen osallistujan toiminnan katsotaan heijastavan hänen tulkintaansa tilanteesta ja muiden osallistujien toiminnasta. Kategoriat, joiden avulla ilmiöitä jäsennetään, nousevat siis osallistujien toiminnasta eivätkä perustu tutkijoiden ennakkokäsityksiin.

Keskustelunanalyysiä on aiemmin käytetty kokousvuorovaikutuksen tutkimiseen erityisesti vuorotteluun ja topiikin valintaan liittyvien piirteiden näkökulmasta (ks. kooste Svennevig, 2012). Suomen kontekstissa kokousten tutkimuksen erityisen huomion kohteena on ollut muun muassa tekstien ja kasvokkaisvuorovaikutuksen suhde (esim. Nissi, 2016; Pälli, 2009). Tämän artikkelin fokuksessa ovat kuitenkin osallistumiseen liittyvät kysymykset: kieltä vaihtamalla voidaan parantaa omia tai muiden osallistujien 
mahdollisuuksia osallistua kokousvuorovaikutukseen. Osallistumisen säätelyn keinona kielenvaihto rinnastuu esimerkiksi prosodisiin ja kehollisiin käytänteisiin, joilla kokouksissa pyritään kohdistamaan puhetta tietyille vastaanottajille ja varmistamaan näiden huomio (Ford \& Stickle, 2012; Markaki \& Mondada, 2012).

Aiemman tutkimuksen perusteella tiedetään, että monikielisissä kokouskonteksteissa kielenvaihdot voivat toisaalta rajoittaa tai toisaalta mahdollistaa kokoukseen osallistumista (Markaki, Merlino, Mondada, Oloff \& Traverso, 2012) ja että kielenvaihtoja hyödynnetään myös identiteettien ja affiliaatioiden ilmaisemiseen (Vöge, 2011). Omassa aineistossamme on runsaasti erilaisia kielenvaihtoja, joista osan voi liittää edellä mainittuihin funktioihin. Keskitymme tässä artikkelissa kuitenkin erityisesti sellaisiin tilanteisiin, joissa yhteisessä keskustelussa vaihdetaan kieltä jonkinlaisen vuorovaikutuksen ongelman seurauksena. ${ }^{21}$ Se, että ongelma pyritään ratkaisemaan kieltä vaihtamalla, viittaa kielenvaihtajan tulkitsevan ongelman johtuvan kielitaidosta. Tällaisia kielenvaihtoja tarkastelemalla pääsemme käsiksi siihen, miten osallistujat pyrkivät sujuvoittamaan vuorovaikutusta ongelmatilanteissa ottamalla kielitaidon rajoitteet huomioon. Keskeiseksi nousee paitsi kielenvaihtajan oma kielitaito myös hänen arvionsa toisten osallistujien kielitaidosta. Rajaus nostaa siis tarkasteltavaksi yhden keskeisen keinon, jota käytetään

\footnotetext{
${ }^{2}$ Kielenvaihdot jakautuvat aineistossa epätasaisesti, mutta ne kokoukset (yhteensä noin $8 \mathrm{~h}$ ), joissa kieltä vaihdellaan usein, sisältävät karkeasti arvioituna keskimäärin 15 kielenvaihtoa tunnissa; aineiston kokonaisuudessa tämä tarkoittaisi siis vähintään noin 120:tä kielenvaihtoa. Näistä - edelleen hyvin karkeasti arvioituna - noin neljäs- tai viidesosa näyttäisi liittyvän vuorovaikutuksen ongelmiin. Emme kuitenkaan ole laskeneet tapausten tarkkaa lukumäärää, sillä tavoitteenamme on ollut pikemminkin ymmärtää tarkastelun kohteena olevaa ilmiötä kuin vertailla sen yleisyyttä joihinkin muihin ilmiöihin tai esittää tarkkoja kategorisointeja.
}

monikielisen kokousvuorovaikutuksen ongelmien ratkaisemiseen. Käsittelemme ensin tapauksia, joissa puhuja vaihtaa kieltä omaan oletuskieleensä.

\section{VAIHTO OMAAN OLETUSKIELEEN}

Nevilen ja Wagnerin (2011) esittämän ajatuksen mukaan yksi tyypillinen kielenvaihdon konteksti on sellainen, jossa osallistuja vaihtaa kieltä omaan oletuskieleensä. Esitämme tässä jaksossa kaksi esimerkkiä, joista ensimmäisessä puhuja vaihtaa venäjään ja toisessa suomeen. Kielenvaihdon kontekstit ovat esimerkeissä hieman erilaiset, mutta niitä yhdistää se, että puhuja ratkaisee syntyneen ongelman tekemällä vaihdon itselleen vahvempaan kieleen.

Esimerkki 1 on kokouksesta, johon osallistuvat järjestön työntekijöistä Olga, Jenni ja Risto sekä järjestön ulkopuolinen (video)kuvaaja Anatoli (osallistujien nimet on muutettu; esimerkit on litteroitu keskustelunanalyysin konventioiden mukaan, ks. liite 1). Kokouksessa suunnitellaan Anatolin kuvaustehtäviä järjestön tapahtuman yhteydessä. Kaikki osallistujat osaavat sekä suomea että venäjää, mutta heidän kielitaitonsa vaihtelee. Esimerkin 1 kielenvaihtaja, Olga, on äidinkieleltään venäjänkielinen. Hän puhuu ja ymmärtää suomea, mutta käyttää aineiston perusteella (erityisesti aineiston keruujakson alkupuolella, josta esimerkki on) useammin venäjää silloin, kun kaikki osallistujat ymmärtävät sitä (ks. myös esimerkki 2). Kokouksen alussa on yhdessä päätetty käyttää kokouskielenä suomea, sillä venäjänkielinen Anatoli on ilmaissut haluavansa harjoitella suomen puhumista. Katkelma alkaa tilanteesta, jossa järjestön johtaja Risto on juuri kuvaillut laveasti aiempaa kokemustaan, joka voisi toimia videoiden teon mallina. 
Esimerkki 1. Minä puhun venäjäksi.

01 Risto: osit- välil mä * te:i ja välil hä $[n$ teki.

${ }^{*} R$ kääntää katseen O:aan

02 Olga:

$\left[{ }^{\circ} \mathrm{m} \mathrm{joo.}{ }^{\circ}{ }^{\circ}\right.$ okei ${ }^{\circ}$

$03 \quad$.hhhhhhh (0.7) hhhhhhhhhh

$04 \quad(0.5)$

05 Risto: no ni * pitää pääs[tä êteempäi. hhhh

*kädenliike kohti O:aa

06 Olga: ['okei.

$07 \quad{ }^{\circ}<\uparrow$ okei $>{ }^{\circ}$,.$h h h h h h$ hh (0.2) hhhh minä hhhh

08 puhun s- (0.2) venäjäksi. hhhih hih hi [hi hi£

09 Risto: $\quad$ [puhu.

10 Olga: $\quad$ hhih .hhhh okei (--)£. (0.2) .hhh $\downarrow$ (koska)

$11 \quad *$ joo hän puhuu ja puhua ja kaks kieltä $\downarrow$.

* vilkaisee A: a ja heilauttaa kättään häntä kohti

$12 \quad(0.2)$

13 Risto: joo.

--> Olga: .hhhhhh (0.3) a:::m:: podderživaju ideju korotkogo

15 tizera, minuty i: vot čego-to dlinnogo, to,

16 čto ty govoriš zz vot $s$ ètimi voprosami, dialogami

17 korotkimi nemnožko o soderžanii

'kannatan ideaa lyhyestä, minuutin videosta ja

jonkinlaisesta pitkästä, niin kuin sinä puhuit, jossa on

kysymyksiä, lyhyitä dialogeja ja vähän sisällöstä’

Päästyään kuvauksensa loppuun (rivi 1) Risto kääntää katseen Olgaan. Hän ilmaisee näin odottavansa Olgalta kommentteja. Koska Olga vastaa suunnitteilla olevan tapahtuman venäjänkielisestä viestinnästä, hän on avainhenkilö myös haastattelujen kuvaamisen suunnittelussa (deonttisten roolien näkymisestä vuorovaikutuksessa esim. Stevanovic \& Peräkylä, 2012). Olga rekisteröi häneen kohdistuvan odotuksen ja ilmaisee responssipartikkeleilla (joo, okei) ottavansa vuoron (r. 2). Partikkeleita seuraa kuitenkin sisäänhengitys, huokaus ja tauko, jotka kertovat, että vuoron tuottamisessa on ongelmia (r. 3-4). Risto reagoi tähän hoputtamalla: hän orientoituu keskustelun tavoitteellisuuteen ilmaisemalla sanallisesti, että keskustelun pitäisi edetä, ja viittaa samalla kädellään kohti Olgaa (r. 5). Olga reagoi uudelleen responssipartikkeleilla (okei) ja vetää hymyillen henkeä (r. 6-7). Kuuluva hengen vetäminen ilmaisee jälleen, että hänen on vaikea tuottaa vuoroa, vaikka häneltä selvästi odotetaan kannanottoa. Olgan asema on kiusallinen: osoittaakseen muille osallistujille, että hän on pätevä työtehtäväänsä, hänen olisi kyettävä esittämään mielipiteensä. Olgan hymy ei ole niinkään osoitus tilanteen huvittavuudesta kuin ongelmallisuudesta: hymy ja nauru voivat usein olla keinoja käsitellä ongelmallista tai arkaluonteista toimintoa (esim. Haakana, 2010, s. 1509). 
Olga ratkaisee ongelman vaihtamalla omaan oletuskieleensä venäjään. Hän ei kuitenkaan tee sitä suoraan, vaan eksplikoi ensin - edelleen hymyillen - kielenvaihdon suomen kielellä (ks. liioitellun selkeästi artikuloitu minä pubun venäjäksi, r. 7-8). Vuoron lopussa Olga nauraa. Kyse ei enää ole ainoastaan vuoron tuottamisen vaikeudesta vaan myös siitä, että Olga poikkeaa kokouksen alussa sovitusta kielivalinnasta. Nauru on siis väline, jonka avulla voidaan käsitellä paikallisten sosiaalisten normien rikkomista (Vöge, 2011, s. 260). Muut osallistujat eivät lähde mukaan Olgan nauruun; kun nauru liittyy ongelmista kertomiseen, vastaanottaja ei yleensä yhdy siihen (Jefferson, 1984, s. 367). Risto ikään kuin antaa Olgalle luvan vaihtaa kieltä (pubu, r. 9), minkä jälkeen Olga vielä perustelee tai selittää kielen valintaa ( $\mathrm{r}$. 10-11) ja Risto hyväksyy selityksen responssipartikkelillajoo (r. 13). Tämän jälkeen Olga alkaa kommentoida aiempia ehdotuksia venäjäksi (r. 14).

Esimerkin 1 kielenvaihto on kehystetty, eli kokouksen osallistujat nostavat sen vuorovaikutuksessa merkittäväksi: kielenvaihtaja perustelee ja muut osallistujat kommentoivat vaihtoa (ks. Markaki ym., 2012). Tarve eksplikoida kielenvaihto syntyy tässä ainakin siitä, että kokouskieleksi on tapaamisen alussa yhdessä sovittu suomi. Osallistujat ovat siis tehneet eräänlaisen kielisopimuksen (Eskildsen \& Theodorsdóttir, 2017), ja Olga tulkitsee, että sopimuksesta poikkeaminen vaatii perustelua. Samalla sovitusta normista poikkeaminen tekee näkyväksi Olgan tilanteeseen nähden puutteellisen kielitaidon, mikä on jossain määrin arkaluonteista ja näkyy hymyilynä ja nauruna. Risto kannustaa Olgaa vaihtamaan kieltä ja orientoituu näin keskustelun tavoitteellisuuteen ja tarpeeseen edetä. Vuorovaikutuksen etenemisen näkökulmasta tämä on odotuksenmukaista: esimiehenä Risto tietää, että Olga pystyy selittämään asiansa venäjäksi nopeammin ja tarkemmin kuin suomeksi, eikä venäjänkielisen puheen seuraaminen kuormita muita osallistujia merkittävästi. Venäjää voi siis pitää tilanteessa tarkoituksenmukaisena valintana.

Vaihdon perusteleminen - ja mahdollinen pahoittelu - liittyy aineistossamme paitsi edellisen kaltaisiin tilanteisiin, joissa kielenvaihto ei vastaa ennalta sovittua kielivalintaa, myös ylipäätään tilanteisiin, joissa kieltä vaihdetaan ensimmäisen kerran kokouksen aikana. Monissa tapauksissa ensimmäistä vaihtoa seuraavat vaihdot tehdään ilman kommentointia: oma oletuskieli saatetaan siis jo ensimmäisellä kerralla kaikkien tietoon. Osin tästä syystä kehystämättömiä kielenvaihtoja esiintyy aineistossamme selvästi enemmän kuin kehystettyjä. Seuraava esimerkki havainnollistaa tällaista kehystämätöntä kielenvaihtoa. Esittelemämme katkelma sijoittuu kuusi minuuttia edellisen esimerkin jälkeen samassa kokouksessa, ja siinä suunnitellaan samaa tilaisuutta kuin esimerkissä 1. Ensimmäisen esimerkin kielenvaihdon jälkeen kokouksessa on puhuttu venäjää (eli kokouksen alussa tehty sopimus suomen kielen käytöstä ei enää päde). Esimerkin 2 aikana kieli vaihtuu suomeen; kielenvaihtaja on tällä kertaa äidinkieleltään suomenkielinen Risto, joka puhuu sujuvaa joskaan ei kieliopillisesti virheetöntä venäjää. Hän puhuu katkelman alussa venäjäksi kameran sijoituspaikasta argumentoiden sen puolesta, että ihmiset unohtavat kameran ja toimivat luontevasti, mikäli kamera sijoitetaan nurkkaan kuvaamaan. Tämän ajatuksen esittäminen ei kuitenkaan onnistu sujuvasti, vaan Riston vuoro katkeaa riveillä 3-4 epäonnistuneeseen sanahakuun: 
Esimerkki 2. Me unohdetaa se kamera.

01 Risto: kak èto budet vlijat' esli tam v ugle budet kamera 'miten se vaikuttaa jos nurkassa on kamera' kotoraja snimaet vso ra- vso vremja 'joka kuvaa kaikki tas- koko ajan' to ètot (.) nu my privlekajem i tak (.) privyk- (0.4) 'niin (.) me kiinnitetään ja näin (.) totu-'

04 *nu $(0.3)$ nu [(prvk)kak 'niinku (0.3) niinku "prvk"-- kuin'

${ }^{*} R$ sulkee silmät, kääntää päänsä alaviistoon ja heilauttaa kättään

05 Anatoli: [mhym::

06 Olga: [mhym::h

07 Risto: daa::

08 Olga: $\quad$ na [s”jomku) .hhh $\uparrow$ ja-

'kuvaamiseen minä'

--> Risto: $\quad\left[{ }^{*}\right.$.hhhh hh me: unnohdetaa se [kamera $\downarrow$ siel on $\downarrow$

${ }^{*} R$ avaa silmät, vilkaisu O:aan

10 Anatoli: [joo.

11 Risto: sịtte jos meil on kạmera joka kulkee tässä

12 ni[nkun,

13 Olga: [joo.

14 Anatoli: j:oo.

15 Olga èto [nervirujet, ja uverena, i finnov ja dumaju

'olen varma, se hermostuttaa suomalaisia'

16 Risto: [ni-

17 Olga: v pervuju očered' mnje kažetsja

'etenkin heitä mun mielestä'

Katkelman alussa Risto pohjustaa venäjäksi ajatuksensa nostamalla esiin kysymyksen, miten nurkassa seisova kamera vaikuttaa ihmisiin (r. 1-2). Hän alkaa vastata esittämäänsä kysymykseen, mutta törmää kielellisiin ongelmiin. Ensin hän tuottaa verbimuodon privlekajem ('kiinnitämme', r. 3), joka sopii merkitykseltään huonosti kontekstiin ja jota Risto ilmeisesti ei tavoitellut. Tästä kertoo verbimuotoa seuraava sanahakujakso: Risto tuottaa ensin kesken jäävän muodon privykja vielä pienen tauon jälkeen hyvin epäselvän äännejonon, josta kuitenkin kuuluvat samat konsonantit prvk. Sananhaku näkyy myös ke- hollisessa toiminnassa: Risto sulkee silmänsä, kääntää päänsä alaviistoon ja heilauttaa kättään. Riston voi arvailla hakevan verbiä privykaem ('totumme') tai saman verbin kieliopillisesti korrektimpaa perfektiivistä muotoa privyknem.

Vaikka Risto ei lopulta tuota kokonaan kumpaakaan näistä verbimuodoista, keskustelun muut osallistujat ilmaisevat ymmärtävänsä, mitä hän ajaa takaa. Tämä näkyy siitä, miten sekä Olga että Anatoli tuottavat ymmärtämistä osoittavan dialogipartikkelin (r. 5 ja 6, ks. esim. Gardner, 2001), samanaikaisesti Riston rivin 4 epäselvästi tuotetun 
prvk-äännejonon kanssa. Olga jatkaa vielä tuottamalla hieman hajamielisen oloisesti ilmauksen na s' 'jomku ('kuvaaminen' akkusatiivimuodossa), joka sopii muotonsa puolesta huonosti kontekstiin (privykaem ja privyknem vaatisivat muotoa na s' 'jomkoi) mutta joka merkityksen osalta täydentää Riston kesken jäänyttä vuoroa.

Risto ei kuitenkaan tyydy tähän. Hän ensin ikään kuin lopettaa epäonnistuneen sanahakunsa partikkelilla da ('kyllä, r. 7). Samalla kun Olga on aloittamassa uutta lausetta pronominilla ja ('minä, r. 8), Risto vetää henkeä ja saattaa loppuun argumenttinsa toteamalla painokkaasti suomeksi me unohdetaa se kamera (r. 9). Vaikka sekä Olga että Anatoli ovat periaatteessa ilmaisseet ymmärtäneensä, mitä Risto ajaa takaa, Risto siis tuottaa suomenkielisen parafraasin kesken jääneelle venäjänkieliselle lauseelle. Tämän jälkeen Risto jatkaa vuoroaan suomeksi esittämällä toisen näkökulman (r. 11 eteenpäin). Esimerkissä Riston kielellinen ongelma, eli vaikeus tuottaa oikeaa verbimuotoa, johtaa kielenvaihtoon venäjästä suomeen. Risto ei perustele kielenvaihtoa, vaan hänen suomenkielinen vuoronsa jatkaa venäjänkielistä, kesken jäänyttä vuoroa.

Tähän mennessä olemme esitelleet kaksi esimerkkiä, joissa kielenvaihtoihin liittyy jonkinlainen kielitaidon tilanteinen "riittämättömyys". Se näkyy esimerkissä 1 Olgan puheenvuoron viivästymisenä ja esimerkissä 2 Riston sanahakuna ja takelteluna. Kummassakin tilanteessa on painetta vuoron nopeaan tuottamiseen: esimerkissä 1 esimies kehottaa puhujaa etenemään ja esimerkissä 2 puhuja joutuu kilpailemaan vuorosta. Kielitaidon tilanteisen riittämättömyyden aiheuttama ongelma ratkaistaan siis esimerkkien kaltaisissa tapauksissa vaihtamalla puhujalle vahvempaan kieleen. Myös muiden kuin kielenvaihtajan reaktiot kertovat orientoitumisesta vuorovaikutuksen etenemiseen (progressivity, Stivers \& Robinson, 2006; Schegloff, 2007).
Muut eivät esimerkiksi arvostele vaihtoja, vaan pyrkivät jatkamaan keskustelua mahdollisimman keskeytyksettömästi, mikä vastaa esimerkiksi Firthin (1996; 2009) English as lingua franca -kontekstista tekemiä havaintoja, joiden mukaan työtilanteissa toisten kielitaitoon liittyvistä asioista ei yleensä tehdä erityistä numeroa. Esimerkissä 1 Risto kehottaa Olgaa siirtymään eteenpäin uudella kielellä, ja esimerkissä 2 sekä Olga että Anatoli tuottavat samanlaisia ymmärrystä ilmaisevia dialogipartikkeleita ennen kielenvaihtoa ja sen jälkeen. Tämä pyrkimys sujuvuuteen näkyy hyvin myös silloin, kun kieltä vaihdetaan vastaanottajan vahvempaan kieleen. Esittelemme tällaisia tapauksia artikkelimme toisessa jaksossa. Keskiöön nousee paitsi vuorovaikutuksen etenemisen varmistaminen myös osallistujuuden säätely.

\section{VAIHTO VASTAANOTTAJAN OLETUSKIELEEN}

Edellisen jakson esimerkeissä osallistuja vaihtaa kieltä omaan oletuskieleensä. Kokousaineistossamme on kuitenkin myös tästä periaatteesta poikkeavia esimerkkejä, joissa osallistujat vaihtavat kieltä vastaanottajan oletuskieleen (ks. myös Nevile ja Wagner, 2011, esimerkit 4 ja 5). Seuraava esimerkki on kokouksesta, johon osallistuvat järjestön työntekijät Risto ja Katja sekä järjestön ulkopuolinen Georgi. Georgi on venäjänkielinen, mutta hänen suomen kielen taitonsa on niin hyvä, että kokousta käydään pääosin sujuvasti sekä suomeksi että venäjäksi. Kokouksen tavoitteena on pohtia, kannattaako järjestön lähteä hakemaan erästä projektirahoitusta. Jos rahoitusta haetaan, Georgi on ehdolla myös projektin vetäjäksi, joten keskustelussa on myös työhaastattelun piirteitä. Esimerkki 3 on kokouksen alkupuolelta, ja siinä puhutaan Georgin taustasta ja työkokemuksesta. Kokouksen alussa on puhuttu venäjää, mut- 
ta noin minuutin ajan ennen tätä katkelmaa käytetty kieli on ollut suomi. Juuri ennen katkelmaa on puhuttu Georgin englannin kielen taidosta, ja katkelmassa siirrytään puhumaan hänen johtamiskokemuksestaan.

\section{Esimerkki 3. EU-projekti.}

01 Risto: mut sullon kokemusta kuitenki [siitä.

02 Georgi:

$[\uparrow \mathrm{mm}-\mathrm{mm}$,

03 Risto: .hh elikkä ootsä ollu projektin johtajana päällikkönä

04 tämmösellä *eeuuprojektilla.

$$
{ }^{*} R: n \text { katse G:iin }
$$

05 Georgi: mm,

$06 \quad$ (0.9) ((G nostaa kulmia, nyökkää hieman $))$

--> Risto: ty byl kak ot *个vetsvennyi [za, ]

$$
{ }^{*} G \text { nyökkää }
$$

'oletko sinä ollut vastuuhenkilö (jossain)'

08 Georgi:

$$
\text { [ja byl ] }
$$

ja byl v FARO aaaaa projektipäällikkö

'olin olin farossa projektipäällikkönä'
Risto esittää ensin deklaratiivilauseella yhteenvedon Georgin edellä esiin tuomista seikoista, jotka koskevat tämän kykyä pärjätä englanniksi työtehtävissä (r. 1). Riston vuoro loppuu laskevaan intonaatioon. Georgi vahvistaa Riston yhteenvedon dialogipartikkelilla $m m-m m$, joka alkaa melko korkealta ja laskee hieman loppua kohti (r. 2). Tämän jälkeen Risto esittää Georgille kysymyksen, joka koskee tämän aiempaa kokemusta EU-projektin johtajana (r.3). Vuoron kysyvä funktio ilmenee tässä tapauksessa sanajärjestyksestä (ootsä vs. sä oot). Intonaatio on tässäkin tapauksessa laskeva, kuten suomen kielen kysymyslauseissa yleensä on. Se, että Riston rivin 1 toteava vuoro ja rivien 3-4 kysyvä vuoro eivät intonaatioltaan poikkea toisistaan, voi tehdä jälkimmäisen vuoron tunnistamisen kysymykseksi vaikeammaksi. Kysymyksen aikana Risto joka tapauksessa myös kääntää katseensa Georgiin, mikä korostaa Riston odottavan Georgilta vastausta. Georgi rea- goi nyt lyhemmällä partikkelilla $m m$, joka on tuotettu tasaisella intonaatiolla (r. 4). Palaute kuulostaa niin sanotulta jatkajalta (continuer, Gardner, 2001, s. 117; suomessa Routarinne \& Ogden, 2005, s. 168; Sorjonen, 2001, s. 303), jonka funktio on ilmaista edellinen vuoro vastaanotetuksi ja kehottaa puhujaa jatkamaan. Se ei näin ollen toimi vastauksena Riston kysymykseen.

Georgin palautevuoron ongelmallisuus näkyy vuorovaikutuksen jatkossa: Georgin vuoroa seuraa tauko (r. 6), eli Risto ei vahvista Georgin vastausta eikä myöskään siirry seuraavaan kysymykseen. Tauon aikana Risto ja Georgi katsovat toisiaan, ikään kuin kumpikin odottaen toisen reaktiota. Tauon lopussa Georgi kohottaa kulmiaan ja nyökkää Ristoon päin, minkä voi tulkita kehollisin keinoin tuotettuna kehotuksena Ristolle jatkaa puhetta. Risto ottaakin vuoron, mutta sen sijaan että hän veisi keskustelua eteenpäin, hän toistaa esittämänsä kysymyksen 
(ns. second attempt, Auer, 1998), tällä kertaa venäjäksi (r. 7). Georgi reagoi kysymykseen nopeasti nyökkäämällä ja aloittamalla vastaamisen jo ennen kuin Risto on päässyt vuoronsa loppuun (r. 8). Georgin vastaus alkaa heti sen jälkeen, kun Riston vuoron otvetsvennyi-sanaan sijoittuva nouseva intonaatio on paljastanut vuoron kysymykseksi. Venäjässä tämäntyyppisen vaihtoehtokysymyksen erottaa väitelauseesta vain nouseva intonaatio (esim. Bolden, 2016, s. 41-42). Voidaankin olettaa, että Georgi on ymmärtänyt jo Riston suomenkielisen kysymyksen sisällön, vaikka ei olekaan hahmottanut, että vuoro on kysymys. Riston venäjänkielisen vuoron alku riittää siis osoittamaan Georgille, että aiempi vuoro oli kysymys.

Esimerkissä 3 Risto tulkitsee Georgin ongelmallisen palautevuoron ymmärtämisen ongelmana ja korjaa tilanteen vaihtamalla kieltä. Kakkoskielisten institutionaalisten keskustelujen korjausjaksoille onkin tyypillistä, että ensikielinen instituution edustaja ottaa enemmän vastuuta vuorovaikutuksen sujuvuudesta: hän esittää oman tulkintansa tilanteesta sen sijaan että siirtäisi vastuun ongelman selvittämisestä toisen kielen puhujalle (Kurhila, 2012). Jo se, että Risto alkaa toistaa samaa kysymystä venäjäksi, osoittaa vuorostaan Georgille, miten Risto on tulkinnut tilanteen. Osoituksena tästä Georgi muuttaa välittömästi oman toimintansa suuntaa vastaamalla kysymykseen. Kielenvaihto tehdään tässä esimerkissä ilman eksplikointia. Ekspli- koinnille ei ole tarvetta, koska kieltä on vaihdeltu jo aiemmin; lisäksi kaikki osallistujat osaavat molempia kieliä. Pelkkä kielenvaihto tekee ymmärtämisen ongelman näkyväksi ja antaa tilaisuuden tilanteen korjaamisen, mutta ei kuitenkaan tematisoi ongelmaa vaan mahdollistaa keskustelun sujuvan etenemisen.

Vastaanottajan oletuskieleen vaihtamista tapahtuu myös tilanteissa, joihin ei liity vastaavia näkyviä ymmärtämisen ongelmia mutta joissa vastaanottajan aktiivinen vastaanottajuuden osoittaminen vähenee tai lakkaa. Puhuja voi tulkita kuulijan passivoitumisen merkiksi esimerkiksi siitä, että tilanne on käymässä vastaanottajalle kuormittavaksi, tai siitä, ettei vastaanottaja koe olevansa tilanteessa puheen ensisijainen vastaanottaja. Seuraava esimerkki on samasta kokouksesta kuin edellinen, mutta tässä vaiheessa kokous on kestänyt jo noin tunnin ajan. Risto, Katja ja Georgi keskustelevat EU-rahoitushakemuksen tekemisestä. Risto seisoo fläppitaulun luona hakemuspaperit kädessään. Viimeisten noin kymmenen minuutin ajan hän on puhunut lähinnä suomeksi piirtäen samalla fläppitaululle. Katja ja Georgi istuvat vastakkain pöydän ääressä. Katkelman kielenvaihtaja on Katja, joka käyttää aineistossa tasaveroisesti sekä äidinkieltään venäjää että erittäin sujuvaa suomea. Katkelma alkaa Katjan puheenvuorolla. Hän katsoo Ristoa ja Georgi katsoo Katjaa; Riston katse on papereissa lähes koko katkelman ajan.

Esimerkki 4. Open calleja.

01 Katja: .hhh ju $\uparrow u \downarrow$ ujuu mut $\uparrow$ sielä on: $\uparrow$ ja sit ninku me voidan (.) ja voidan ninku kattoa myös näistä (.) meidän edellisistäki projekteista siellä tullee näin *et se. .hhhh et s- e- (0.2) et et et kyl:

${ }^{*} G$ :n katse pöytään me (0.9) osataa vastat- ninku hakkemusta varten 


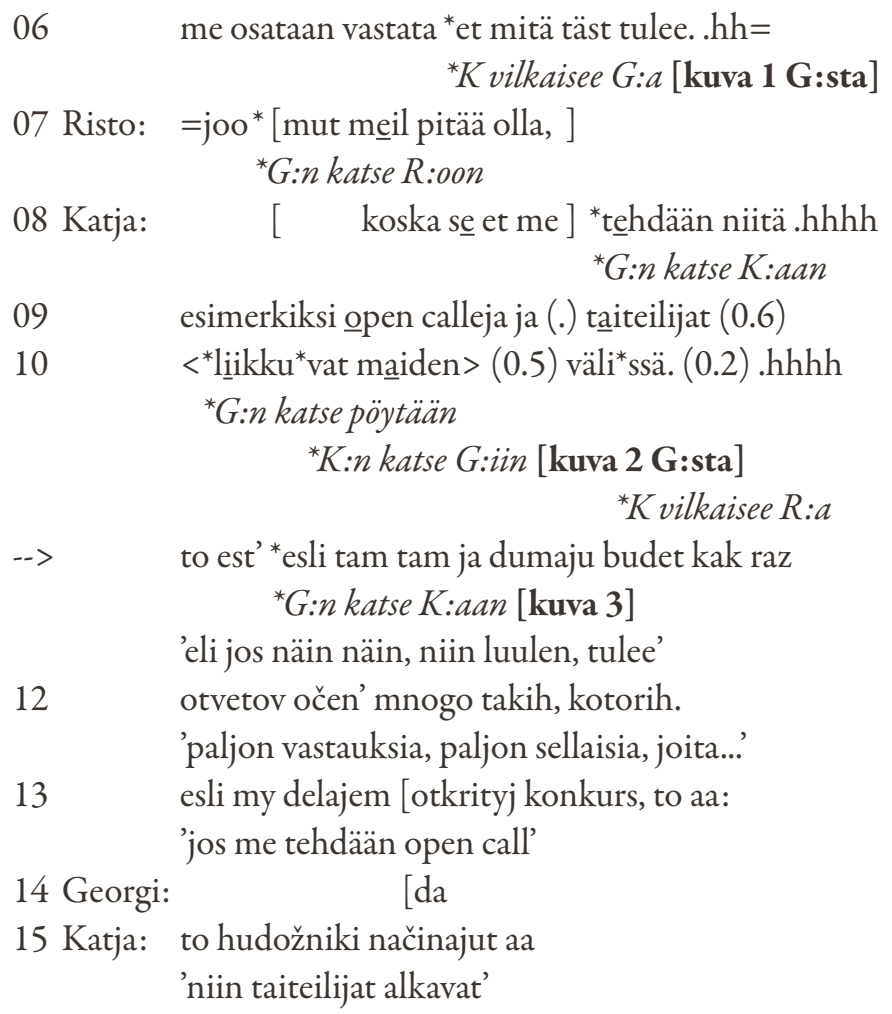

Katja reagoi suomeksi Riston edeltävään, suomenkieliseen puheenvuoroon kertomalla, millaisia valmiuksia heillä olisi suunnitteilla olevan hakemuksen tekemiseen (r. 1-). Katjan katse on Ristossa. Vuoron aikana Georgin katse siirtyy Katjasta alas pöytään (r. 4). Georgin katse on edelleen pöydässä, kun Katja hieman myöhemmin vilkaisee tämän suuntaan (r. 6, kuva 1). Lyhyen vilkaisun jälkeen Katjan katse kiinnittyy uudelleen Ristoon. Risto ottaa tässä vaiheessa vuoron, jolloin myös Georgin katse siirtyy Ristoon (r. 7). Katja jatkaa kuitenkin omaa vuoroaan päällekkäispuhunnassa Riston kanssa (r. 8), jolloin tämän vuoro jää kesken. Tässä vaiheessa Georgin katse siirtyy hetkeksi Katjaan (r. 8), mutta laskee pian uudelleen pöytään (r. 10). Georgin ilme osoittaa jonkinlaista disorientoitumista: katse on jähmettynyt paikalleen, ja suu on vääntynyt toiselle puolelle (kuva 2). Georgi näyttää poissaolevalta vielä, kun Katja katsoo tätä hetkeä myöhemmin (r. 10).
Katja on siis voinut havaita Georgin katsovan pöytää jo kahdesti oman vuoronsa aikana (r. 6 ja 10; kuvat 1-2). Vastaanottajan katseen siirtyminen pois puhujasta voi aiheuttaa sen, että puhujalla on tarve varmistaa vastaanottajan huomio (Goodwin, 1981). Jatkaessaan vuoroaan tilanteessa, jossa Georgi ei katseellaan aktiivisesti osoita vastaanottajuutta, Katja vaihtaa kieltä: katsottuaan Georgia toisen kerran Katja saattaa suomenkielisen vuoronsa loppuun ja vilkaisee sen lopussa vielä lyhyesti Ristoa (r. 10), mutta sen jälkeen hän vetää henkeä ja jatkaa puhetta venäjäksi katse Georgissa (r. 11). Venäjänkielisen vuoron sisältö jatkaa saumattomasti edeltävän suomenkielisen vuoron aihetta eikä siis toista suomeksi sanottua, joten kyse ei ole korjaamisesta (vrt. esimerkit 2 ja 3). Kielen vaihtaminen on yksi keino muotoilla vuoro tunnistettavaksi tietylle vastaanottajalle (ns. recipient design, Sacks, Schegloff \& Jefferson, 1974), ja siten kieltä vaihtamalla Katja suuntaa vuoronsa vahvem- 
min Georgille. Georgi reagoi kielenvaihtoon siirtämällä välittömästi katseensa Katjaan (r. 11, kuva 3). Hän siis osoittaa heti vaihdon jälkeen aktiivisesti vastaanottajuuttaan, mikä näkyy myös hetkeä myöhemmin hänen tuottamassaan partikkelissa (da, r. 14). Katkelman

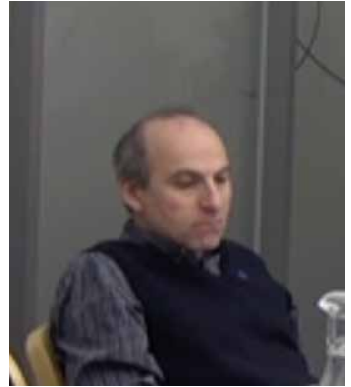

Kuva 1

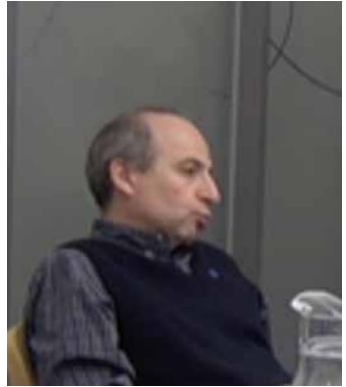

Kuva 2

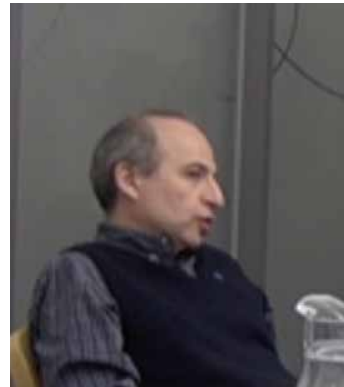

Kuva 3

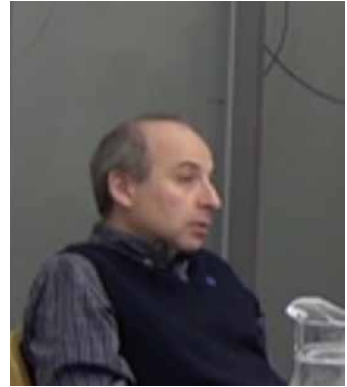

Kuva 4 jälkeen Georgi aktivoituu yhä näkyvämmin tuottamalla useita responssipartikkeleja ja auttamalla Katjaa sanahaussa (kuva 4, 18 sekuntia kielenvaihdon jälkeen).

Esimerkki 4 osoittaa, miten puhuja voi katseellaan monitoroida vastaanottajia varmistuakseen näiden huomiosta. Jos vastaanottajat eivät aktiivisesti osoita vastaanottajuutta, puhuja voi pyrkiä aktivoimaan heitä suuntaamalla vuoronsa vahvemmin juuri heille. Pelkkä katseen siirtäminen aktivoitavaan vastaanottajaan ei aina riitä, koska tämä ei välttämättä havaitse muutosta katsoessaan itse muualle; tarvitaan siis äänellinen elementti. Puhuttelutermi tai huomiopartikkeli katkaisisi vuoron etenemisen ja tematisoisi huomion hakemisen. Monikielisessä keskustelussa, jossa kielten vaihtelu ei ole poikkeuksellista, vastaanottajan oletuskieleen vaihtaminen on taloudellinen keino osoittaa, että puhuja suuntaa vuoronsa erityisesti hänelle. Jos passivoituminen on johtunut siitä, että tilanne on kuormittava muuta kuin oletuskieltään käyttävälle, kieltä vaihtamalla voidaan keventää osallistumisen aiheuttamaa rasitusta. Jos taas vastaanottaja on passivoitunut, koska hän ei koe olevansa puheen ensisijainen vastaanottaja, kielenvaihto osoittaa, että puhe on todella tarkoitettu (myös) hänelle.

Kielenvaihtoja tehdään aineistossamme muidenkin periaatteiden kuin oman oletuskielen käyttämisen periaatteen mukaan, mistä osoituksena toimivat tämän jakson esimerkit 3 ja 4 . Ne näyttävät, että kielenvaihto voi olla tuloksellinen keino vuorovaikutuksen ongelmien selvittämiseen myös silloin, kun se tehdään vastaanottajalle vahvempaan kieleen. Esimerkissä 3 kielenvaihto johtaa hyvin nopeaan väärinymmärryksen selvittämiseen. Esimerkki 4 on vastaava: Georgi aktivoituu hyvin nopeasti kielenvaihdon jälkeen ja osoittaa usein tavoin aktiivisesti vastaanottajuuttaan ja osallistumistaan.

\section{LOPUKSI}

Olemme edellä pyrkineet osoittamaan, että kielenvaihdot ovat aineistomme osallistujille keino tasapainoilla kokoustilanteen moninaisten vaatimusten välillä. Niiden avulla pyritään ylipäänsä maksimoimaan vuorovaikutuksen tehokas eteneminen. Kielenvaihtoja tehdään niin omaan kuin vastaanottajan kielitaitoon orientoituen niin, että institutionaaliset tavoitteet eli kokouksen agenda etenee. Tämä voi tarkoittaa joko vaihtamista 
itselle vahvempaan ja näin ollen tehokkaampaan kieleen (esimerkit 1-2) tai vaihtamalla vastaanottajalle helpompaan kieleen ymmärryksen ja vastaanottajuuden varmistamiseksi - ja ehkä myös tilanteen aiheuttaman kuormituksen helpottamiseksi (esimerkit 3-4). Tämä pyrkimys etenemiseen näkyy paitsi kielenvaihtajan toiminnassa myös muiden tilanteeseen osallistujien vuoroissa. Silmiinpistävää on, että kielenvaihtoja ei aineistossa vastusteta kuin ehkä piilevästi pitäytymällä aiemman kielen käyttämisessä. Silloin kun kielenvaihtoa kommentoidaan jotenkin, on kommentointi vuorovaikutusta eteenpäin vievää (esimerkki 1).

Käytännön työelämän kannalta edellä sanottu nostaa esiin eri kielten joustavan vaihtelun hyödyt. Useilla työpaikoilla on kirjattuna tai kirjaamattomana kielipolitiikkana yhden kielen käyttö (ks. esim. Lønsmann \& Mortensen, 2018): työtilanteissa puhutaan esimerkiksi pelkkää lingua franca -englantia tai valtion enemmistökieltä - suomalaisessa kontekstissa siis suomea. Näissä tapauksissa jää kuitenkin hyödyntämättä kielenvaihtojen potentiaalinen kommunikaation ja ylipäänsä työnteon tehokkuutta lisäävä vaikutus. Yhdessä kielessä pitäytymällä työntekijöiden kielivarantoa ei hyödynnetä monipuolisesti ja kyseistä kieltä heikommin osaavien työntekijöiden osallistuminen paitsi erityisesti kokousten vuorovaikutukseen - kuten tämän artikkelin aineistossa - mutta myös yleisemmin työn vaatimiin tehtäviin saattaa estyä. Aiemmassa kirjallisuudessa yhdessä kielessä pitäytymistä tehokkaampana käytänteenä on toisaalta pidetty esimerkiksi reseptiivistä monikielisyyttä (esim. Zeevaert \& ten Thije, 2007) eli käytäntöä, jossa jokainen puhuu itselleen vahvinta kieltä. Muilta vaaditaan siis tällaisissa tilanteissa vain kykyä ymmärtää toisen kieltä. Aineistomme toinen analyysiluku (esimerkit 3 ja 4) osoittaa kuitenkin konkreettisia hyötyjä, joita seuraa siitä, että puhu- ja ottaa huomioon joustavasti myös kuulijan kielen. Tiukkaan harjoitetun reseptiivisen monikielisyyden periaatteen voi myös katsoa vievän osallistujilta mahdollisuuden harjoitella toisen kielen puhumista niin halutessaan.

Työpaikkojen monikielisyyttä ei kannata nähdä pelkästään ongelmana vaan myös voimavarana. Esimerkiksi perinteisesti suomeksi toimineessa työyhteisössä muiden kielten kuin suomen käyttöönotto mahdollistaisi sellaistenkin työntekijöiden palkkaamisen, joiden suomen kielen taito ei ainakaan vielä palkkaamisen aikaan riitä kaikkiin työhön liittyviin tilanteisiin ja tehtäviin. Toisaalta myös suomen kielen käyttäminen mahdollisuuksien mukaan tukisi kakkoskielisten työntekijöiden suomen kielen taidon kehittymistä - ilman mahdollisuuksia kielen käyttöön kielitaito ei kehity (ks. esim. Sandwall, 2013; Strömmer, 2017). Monien kielten käyttäminen ja työpaikan kielivarannon tunnistaminen ehkäisisi myös työntekijöiden kieleen liittyvää syrjäytymistä työpaikan tärkeistä tiedoista tai yhteisöistä (esim. Forsander \& Raunio, 2005; Negretti \& Garcia-Yeste, 2015).

Keinot edistää edellä mainittuja tavoitteita voivat olla hyvin yksinkertaisia. Vaikka aineistomme työpaikka ei edusta aivan tyypillisintä suomalaista työpaikkaa, voisi joustavampi kielipolitiikka olla mahdollista monilla työpaikoilla. Tämä ei kuitenkaan onnistu, jos työntekijät eivät esimerkiksi tunnista toistensa kielitaitoja. Siksi jo pelkkä keskustelu työntekijöiden kielirepertuaareista ja työpaikan konkreettisista kielikäytänteistä voi lisätä työntekijöiden kielitietoisuutta ja tehostaa vuorovaikutuksen käytänteitä.

\section{LÄHTEET}

Angouri, J. (2014). Multilingualism in the workplace: Language practices in multilingual contexts. Multilingua, 33, 1-9.

Auer, P. (1984). Bilingual conversation. Amster- 
dam: Benjamins.

Auer, P. (1998). Introduction: Bilingual conversation revisited. Teoksessa P. Auer (toim.), Codeswitching in conversation: language, interaction and identity, (s. 1-24). London: Routledge.

Bolden, G. B. (2016). A simple da?: Affirming responses to polar questions in Russian conversation. Journal of Pragmatics, 100, 40-58.

Breckle, M. \& Schlabach, J. (2017). Stimmen zu Mehrsprachigkeit in finnischen Unternehmen: Ausgewählte Ergebnisse der LangBuCom-Studie. Teoksessa N. Keng, N., A. Nuopponen \& D. Rellstab (toim.), Ä̈̈niä, Röster, Voices, Stimmen, (s. 29-40). Vaasa.

EK $2014=$ Kielitaito on kilpailuetu. EK:n henkilöstö-ja koulutustiedustelu. Helsinki: Elinkeinoelämän keskusliitto EK. www.ek.fi/henko

Eskildsen, S.W. \& Theodórsdóttir, G. (2017). Constructing L2 learning spaces: Ways to achieve learning inside and outside the classroom. Applied Linguistics, 38, 143-164.

Firth, A. (1996). The discursive accomplishment of normality: On 'lingua franca' English and conversation analysis. Journal of Pragmatics, 26, 237-259.

Firth, A. (2009). Doing not being a foreign language learner: English as a lingua franca in the workplace and (some) implications for SLA. IRAL, 47, 127-156.

Frick, M. (2013). Emergent bilingual constructions - Finnish-Estonian codeswitching in interaction. Väitöskirja. Helsingin yliopisto.

Ford, C. E. \& Stickle, T. (2012). Securing recipiency in workplace meetings: Multimodal practices. Discourse Studies, 14, 11-30.

Forsander, A. \& Raunio, M. (2005). Globalisoituvat työmarkkinat - asiantuntijamaahanmuuttajat Suomessa. Teoksessa P. Pitkänen (toim.), Kulttuurien välinen työ, (s. 26-53). Helsinki: Edita.

Gafaranga, J. (2005). Demythologising language alternation studies: conversational structure vs. social structure in bilingual interaction. Journal of Pragmatics, 37, 281-300.

Gafaranga, J. (2016). Bilingualism as interactionalpractices. Edinburgh: Edinburgh University Press.

Gardner, R. (2001). When listeners talk: Response tokens and listener stance. Amsterdam: John Benjamins.
Goodwin, C. (1981). Conversational organization: Interaction between speakers and hearers. New York: Academic Press.

Gumperz, J. (1982). Discourse strategies. Cambridge: Cambridge University Press.

Haakana, M. (2010). Laughter and smiling: Notes on co-occurrences. Journal of Pragmatics, 42 , 1499-1512.

Hazel, S. \& Mortensen, J. (2013). Kitchen Talk - Exploring Linguistic Practices in Liminal Institutional Interactions in a Multilingual University Setting. Teoksessa H. Haberland, D. Lønsmann \& B. Preisler (toim.), Language Alternation, Language Choice and Language Encounter in International Tertiary Education, (s. 3-30). Dordrecht: Springer.

Hazel, S. \& Svennevig J. (2018). Multilingual workplaces - interactional dynamics of the contemporary international workforce. An introduction. Journal of Pragmatics, 126, 1-9.

Jefferson, G. (1984). On the organization of laughter in talk about troubles. Teoksessa J. M. Atkinson \& J. Heritage (toim.), Structure of social action - Studies in conversation analysis, (s. 347-369). London: Cambridge University Press.

Kalliokoski, J. (1995). Koodinvaihto ja keskustelun moniäänisyys. Virittäjä, 99, 2-24.

Kurhila, S. (2012). Kun ymmärtäminen on vaakalaudalla - kohdentamattomat korjausaloitteet kakkoskielisessä keskustelussa. Teoksessa L. Leskelä \& C. Lindholm (toim.), Haavoittuva keskustelu: Keskustelunanalyyttisia tutkimuksia kielellisesti epäsymmetrisestä vuorovaikutuksesta, (s. 145-183). Helsinki: Kehitysvammaliitto.

Lahti, M. (2015): Communicating interculturality in the workplace. Väitöskirja. Jyväskylän yliopisto.

Lappalainen, H. (2009). Koodinvaihto ja sen funktiot suomenkielisessä keskustelussa. Teoksessa J. Kalliokoski, L. Kotilainen \& P. Pahta (toim.), Kielet kohtaavat, (s. 123-160). Helsinki: Suomalaisen Kirjallisuuden Seura.

Lesk, S., Lavric, E. \& Stegu, M. (2017). Multilingualism in business: Language policies and practices. Teoksessa G. Mautner \& F. Rainer (toim.), Handbook of business communication: Linguistic approaches, (s. 269-317). Berlin: De Gruyter.

Louhiala-Salminen, L. \& Kankaanranta, A. (2012). Language as an issue in international 
internal communication: English or local language? If English, what English? Public Relations Review, 38, 262-269.

Lüdi, G., Höchle Meier, K. \& Yanaprasart, P. (toim.) (2016). Managing plurilingual and intercultural practices in the workplace: The case of multilingual Switzerland, Amsterdam: Benjamins.

Lønsmann, D. (2014). Linguistic diversity in the international workplace: Language ideologies and processes of exclusion. Multilingua, 33, 89-116.

Lønsmann, D. \& Mortensen, J. (2018). Language policy and social change: A critical examination of the implementation of an English-only language policy in a Danish company. Language in Society, 47, 435-456.

Markaki, V., Merlino, S., Mondada, L., Oloff, F. \& Traverso, V. (2012). Choix de langues et gestion de la participation dans les réunions internationales. Teoksessa L. Mondada \& L. Nussbaum (toim.), Interactions cosmopolites. L'organisation de la participation plurilingue, (s. 99-131). Limoges: Lambert Lucas.

Markaki, V. \& Mondada, L. (2012). Embodied orientations towards co-participants in multinational meetings. Discourse Studies, 14, 31-52.

Mononen, K. (2013). Inkerinsuomalaisten suomen kielen käyttö Pietarissa ja sen lähialueella. Väitöskirja. Helsingin yliopisto.

Negretti, R. \& Garcia-Yeste, M. (2015). "Lunch keeps people apart": the role of English for social interaction in a multilingual academic workplace. Multilingua, 34, 93-118.

Nevile, M. \& Wagner, J. (2011). Language choice and participation: Two practices for switching languages in institutional interaction. Teoksessa G. Pallotti \& J. Wagner (toim.), L2 learning as socialpractice: Conversation-analyticperspectives, (s. 211-235). Honolulu: National Foreign Language Resource Center.

Nissi, R. (2016). Kokouskeskustelusta vastinetekstiksi: Yhteisen äänen rekontekstualisointi ja virkatekstin neuvoteltu omistajuus. Virittäjä, 120, 188-217.

Pälli, P. (2009). Strategia merkitysneuvotteluna: Strategiakeskustelun ja -tekstin vuorovaikutuksesta. Pube ja kieli, 29,75-88.

Routarinne, S. \& Ogden, R. (2005). The communicative functions of final rises in Finnish into- nation. Phonetica, 62, 160-175.

Sandwall, K. (2013). Att hantera praktiken. Om sf-studerandes möligheter till interaktion och lärande på praktikplatser. Göteborgsstudier i nordisk språkvetenskap 20. Göteborg: Göteborgs universitet.

Sacks, H., Schegloff, E. \& Jefferson, G. (1974). A simplest systematics for the organization of turn-taking for conversation. Language, 50, 696-735.

Schegloff, E. (2007). Sequence Organization in Interaction: A Primer in Conversation Analysis. Cambridge: Cambridge University Press.

Sorjonen, M.-L. (2001). Responding in conversation: A study of response particles in Finnish. Amsterdam: John Benjamins.

Stevanovic, M. \& Lindholm, C. (toim.) (2016). Keskustelunanalyysi. Kuinka tutkia sosiaalista toimintaa ja vuorovaikutusta. Tampere: Vastapaino.

Stevanovic, M. \& Peräkylä, A. (2012). Deontic Authority in Interaction: The right to announce, propose and decide. Research on Language and Social Interaction, 45, 297-321.

Stivers, T. \& Robinson, J. D. (2006). A preference for progressivity in interaction. Language in Society, 35, 367-392.

Suni, M. (2011). Esipuhe: Suomi toisena kielenä työelämässä. Puhe ja kieli, 31, 137-138.

Strömmer, M. (2017). Mahdollisunksien rajoissa: Neksusanalyysi suomen kielen oppimisesta siivoustyössä. Jyväskylä: Jyväskylän yliopisto.

Svennevig, J. (2012). Interaction in workplace meetings. Discourse Studies, 14, 3-10.

Tanner, J. \& Lassus, J. (2018). Kotimaiset kielet työelämässä: Suomenruotsalaisten raportoimat kokemukset työelämän viestintätilanteista ja saamastaan kielenopetuksesta. Teoksessa L. Lehti, P. Peltonen, S. Routarinne, V. Vaakanainen \& V. Virsu (toim.), Uusia lukutaitoja rakentamassa-Building new literacies, (s. 115-133). AFinLAn vuosikirja 2018. Jyväskylä: AFinLA.

Tarnanen, M. \& Pöyhönen, S. (2011). Maahanmuuttajien suomen kielen taidon riittävyys ja työllistymisen mahdollisuudet. Puhe ja kieli,31, 139-152.

Tervola, M. (2018). Lääkärin työtilanteiden kielellisen vaativuuden määrittäminen. Puhe ja kieli, 38, 83-107.

Virkkula, T. (2008). Työntekijöiden kokemuksia 
englannista yritysmaailman yhteisenä kielenä. Teoksessa S. Leppänen, T. Nikula \& L. Kääntä (toim.), Kolmas kotimainen: Lähikuvia englannin käytöstä Suomessa, (s. 382-420). Helsinki: Suomalaisen Kirjallisuuden Seura.

Vöge, M. (2011). Employing multilingualism for doing identity work and generating laughter in business meetings: A case study. Teoksessa G. Pallotti \& J. Wagner (toim.), L2 learning as social practice: Conversation-analytic perspectives, (s. 237-264). Honolulu: National Foreign Language Research Center.

Zeevaert, L. \& ten Thije, J. D. (2007). Introduction. Teoksessa L. Zeevaert \& J. D. ten Thije (toim.), Receptive multilingualism: Linguistic analyses, language policies and didactic concepts, (s. 1-21). Amsterdam: John Benjamins. 


\section{Liite 1. LITTEROINTIMERKIT}

[] Päällekkäispuhunnan alku ja loppu

$=\quad$ Kaksi lausumaa liittyy toisiinsa tauotta

(1.5) Hiljaisuus, mitattuna sekunteina

(.) 0,2 sekuntia lyhyempi hiljaisuus

Laskeva sävelkulku

Tasainen sävelkulku

sana (Alleviivaus vokaalin alla) tavun painottaminen

${ }^{\circ}$ sana ${ }^{\circ} \quad$ Ympäröivää puhetta hiljaisemmalla äänellä puhuttu jakso

$\uparrow \downarrow \quad$ Nuolen jälkeinen sana tai tavu lausuttu ympäröivää puhetta korkeammalla / matalammalla äänellä

<sana> Ympäröivää puhetta hitaammin puhuttu jakso

sa:na (Kaksoispisteet) edeltävän äänteen venyttäminen

sa- $\quad$ (Yhdysmerkki sanan lopussa) sana jää kesken

(()) Litteroijan selityksiä tilanteesta

( - - ) Sana / jakso, josta ei saatu selvää

.hh Äänekäs sisäänhengitys, yksi kirjain merkitsee 0,1 sekunnin kestoa

* Kehollisen toiminnan alku

hh Äänekäs uloshengitys, yksi kirjain merkitsee 0,1 sekunnin kestoa)

£sana£ Hymyilevällä äänellä puhuttu jakso

'sana' Venäjänkielisen puheen suomenkielinen käännös. Käännökset on pyritty tekemään mahdollisimman pitkälti alkukielisen vuoron mukaisiksi (esim. puheen fragmentaarisuuden säilyttäen), mutta kuitenkin niin, että venäjää osaamaton lukija pystyy hahmottamaan vuorojen sisällön. 


\section{LANGUAGE SWITCHING IN MULTILINGUAL MEETINGS - LANGUAGE PROFICIENCY AND PROGRESSIVITY OF INTERACTION}

Lari Kotilainen, University of Helsinki

Inkeri Lehtimaja, University of Helsinki

Over the recent decades, Finnish working life has become increasingly multilingual: in addition to Finnish and Swedish, employees use e.g. English and various migrant languages. The constantly diversifying language situation has led to challenges in workplace interaction, since employees do not share the same linguistic resources nor are they necessarily competent in all working languages. In this article, we investigate how employees exploit their multilingual work environment in order to secure the progress of the interaction. We focus on moments in which employees switch from one language to another. Our data consist of video-recorded meetings in a cultural organisation in Finland. The most common languages used in the meetings are Finnish and Russian. Our method is ethnomethodological conversation analysis; we study language switches in situ as microlevel practices in interaction. The language switches explored in this article follow problems of progressivity of interaction, including problems of speech production, misunderstandings and inadequate displays of recipiency. On the one hand, we examine how and in which situations participants switch to their own stronger language and, on the other hand, what features contribute to the switch to the stronger language of the recipient. By switching language according to the local circumstantial details of the interaction, the employees secure the progress of the meeting and ensure that all employees may fully participate in the meeting interaction.

Keywords: language switching, language proficiency, meeting interaction, multilingualism, work-related language, progressivity 